\title{
Alat Penala Kendali Proporsional Pada Robot Line Follower Berbasis Website
}

\author{
Taufik Pathu Romdhon ${ }^{1,{ }^{*}}$, Imron Rosyadi ${ }^{1}$, Putra Wisnu A.S ${ }^{1}$, Andi Hasad ${ }^{1}$ \\ * Korespondensi: e-mail: taufikpathur@gmail.com
}

1 Teknik Elektro; Universitas Islam 45 Bekasi; Jl.Cut Mutia No.83 Bekasi Timur 17113, Telepon : (021) 8801027 Fax: (021) 8801192; e-mail: taufikpathur@gmail.com, imronrosyadi746@gmail.com, wisnu@unismabekasi.ac.id, andihasad@yahoo.com

$\begin{array}{ll}\text { Submitted } & : \text { 16 Agustus } 2021 \\ \text { Revised } & : 18 \text { September } 2021 \\ \text { Accepted } & : 23 \text { Oktober } 2021 \\ \text { Published } & : \text { 30 November } 2021\end{array}$

\begin{abstract}
This research is about the proportional control value tuning tool on line follower robots or mobile robots. A mobile robot is one type of robot that can move, where the robot system can move itself from position $A$ to position $B$, and the two positions are separated by $a$ certain distance (the whole body of the robot moves), it can be said that the robot moves dynamically. Speed regulation on the robot requires a control system, one of which is a proportional control system. Proportional control is a control that has an output that is proportional to the magnitude of the error signal the difference between the desired quantity and the actual value. Tuning the proportional constant value using a website server that is created in realtime without the need to reburn the program code in the line follower robot microcontroller. System testing on this tuning device is carried out to determine the delay time and the difference in delivery speed when using a mobile phone cellular network with a Wi-Fi network. At the time of testing the wemos system, the longest delay was 09.50.0 and the fastest was 00.000.8.
\end{abstract}

Keywords: ESP8266, Line Follower, Proportional Control, Tuning Tool.

\section{Abstrak}

Penelitian ini tentang alat penala nilai kendali proporsional pada robot line followers atau robot mobile. Mobile robot merupakan salah satu jenis robot yang dapat bergerak, dimana sistem robot dapat bergerak sendiri dari posisi A ke posisi B, dan kedua posisi tersebut dipisahkan oleh jarak tertentu (keseluruhan tubuh robot bergerak), bisa dikatakan robot tersebut bergerak secara dinamis. Pengaturan kecepatan pada robot dibutuhkan suatu sistem kendali salah satunya sistem kendali proporsional. Kendali proporsional adalah sebuah kendali yang memiliki keluaran yang sebanding dengan besarnya sinyal kesalahan selisih antara besaran yang diinginkan dengan harga aktualnya. Penalaan nilai konstanta proporsional menggunakan server website yang dibuat secara realtime tanpa perlu burning ulang kode program dalam mikrokontroler robot line follower. Pengujian sistem pada alat penala ini dilakukan untuk mengetahui waktu tunda dan perbedaan kecepatan pengiriman pada saat menggunakan jaringan seluler handphone dengan jaringan Wi- Fi. Pada saat pengujian sistem wemos membutuhkan waktu tunda paling lama adalah $09.50,0$ dan paling cepat adalah $00.00,8$.

Kata Kunci: Alat Penala, Kendali Proporsional, Line Follower, ESP8266. 


\section{Pendahuluan}

Mobile robot merupakan salah satu jenis robot yang dapat bergerak, dimana sistem robot dapat bergerak sendiri dari posisi $A$ ke posisi B, dan kedua posisi tersebut dipisahkan oleh jarak tertentu (keseluruhan tubuh robot bergerak), bisa dikatakan robot tersebut bergerak secara dinamis. Mobile robot yang memiliki fungsi khusus dan sering dikembangkan adalah mobile robot line follower. Robot line follower ini menggunakan actuator berupa motor DC untuk bergerak. Pada umumnya driver robot line follower dilengkapi dengan 2 buah motor DC di semua sisi robot. Untuk dapat menggerakan robot, kecepatan masing-masing motor DC diatur oleh rangkaian penggerak motor (Miftahul et al., 2016)

Pengaturan kecepatan pada robot dibutuhkan suatu sistem kendali salah satunya sistem kendali proporsional. Pada pengaturan nilai kendali proporsional diperlukan sebuah alat penala yang dapat mengatur besar dan kecilnya nilai kendali proporsional (Ferdiansyah, n.d.). Pada robot mobile, diperlukan alat penala yang dapat diatur nilainya disaat robot sedang bekerja. Disaat mikrokontroler sedang mengelola pergerakan robot, besar nilai konstanta proporsional harus tetap terjadi tanpa proses burning ulang.

Keberadaan kendali dalam sistem kontrol memberikan kontribusi yang signifikan terhadap perilaku sistem. Salah satu tugas komponen kontroler adalah mengurangi sinyal kesalahan, yaitu perbedaan antara sinyal yang di setting dan sinyal aktual. Hal ini sejalan dengan tujuan dari sistem kendali dimana membuat sinyal aktual selalu sama dengan sinyal yang di setting. Semakin cepat sistem bereaksi terhadap sinyal aktual dan semakin kecil kesalahan yang akan terjadi maka semakin baik kinerja sistem kendali yang diterapkan (Abidin, n.d.).

Robot line follower (robot pengikut garis) adalah robot yang dapat berjalan mengikuti garis pada sebuah lintasan yang sudah ditentukan dan robot ini termasuk dalam kategori jenis robot mobile yang di desain untuk bekerja secara otomatis. Garis yang dimaksud adalah garis berwarna hitam diatas permukaan berwarna putih.

Cara kerja dari sistem robot line follower secara umum ialah dimulai dari pembacaan lintasan atau garis oleh sensor photodiode beserta LED yang mana intensitas pantulan sinar LED akan berbeda jika terkena bidang pantul yang gelap dengan bidang pantul yang lebih terang, dari perbedaan inilah dimanfaatkan pendeteksi lintasan atau garis dan selanjut diketahui nilai parameter ADC (Analog Digital Converter) dari masing-masing sensor garis (Diyati, 2016).

\section{Metode Penelitian}

Gambar 1 merupakan diagram dari metode penelitian pada alat penala konstanta proporsional robot line follower berbasis website, menjelaskan mengenai metode penelitian alat penala konstanta proporsional robot line follower berbasis website ini diawali dengan studi literatur yang dimulai dari mempelajari jurnal, buku, website yang berkaitan dengan alat kendali proporsional. Kemudian Melakukan perancangan dan perakitan pada perangkat keras dan 
perangkat lunak. Selanjutnya dilakukan pengujian dan analisis data dari pengujian yang dilakukan.

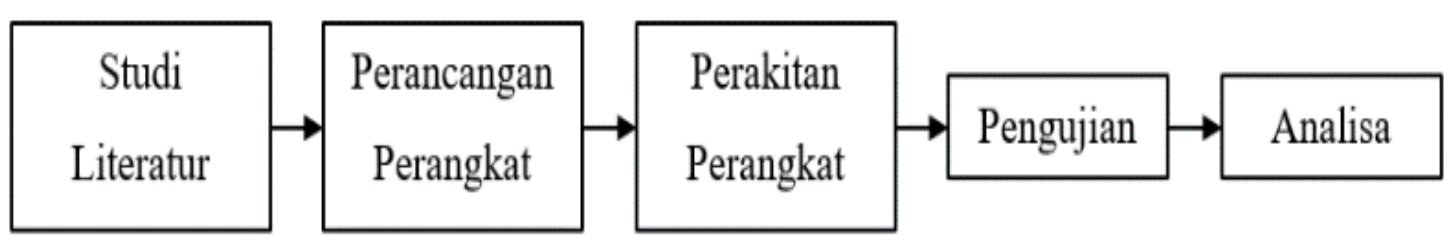

Sumber: Hasil Penelitian (2021)

Gambar 1. Diagram Metode Penelitian

\subsection{Blok Diagram Sistem}

Pada gambar 2 menjelaskan tentang blok diagram sistem dari alat penala kendali proporsional pada robot line follower berbasis website.

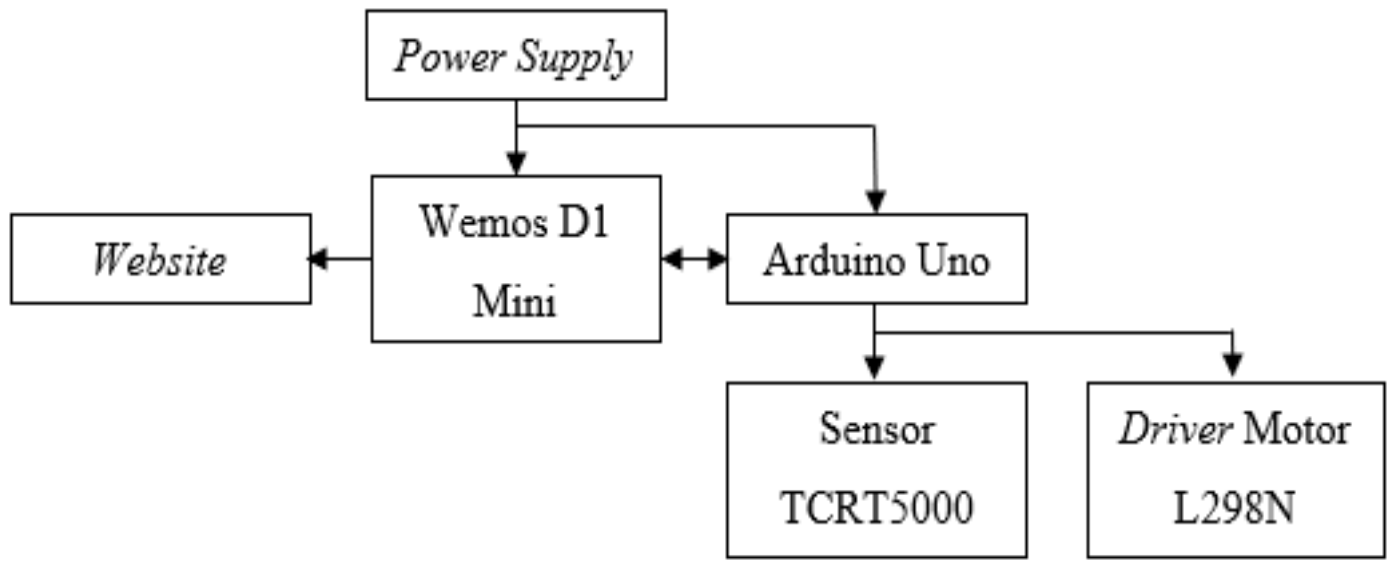

Sumber: Hasil Penelitian (2021)

Gambar 2. Blok Diagram Sistem

Adapun penjelasan fungsi dari blok diagram sistem yaitu sebagai berikut (a) Power Supply berfungsi sebagai pemberi arus dan tegangan ke perangkat komponen-komponen yang ada; (b) Website berfungsi sebagai platform pengirim nilai konstranta proporsional pada perintah yang akan dijalankan; (c) Wemos D1 mini berfungsi untuk menghubungkan data dari website ke arduino uno yang akan diproses (Khalif et al., 2018); (d) Arduino uno berfungsi untuk mengontrol dan memproses data-data input maupun output (Limantara et al., 2017); (e) Sensor TCRT5000 berfungsi untuk mengatur jalannya robot sehingga tidak keluar jalur yang telah ditentukan; (f) Driver motor L298N berfungsi sebagai perangkat yang akan memerintahkan gearbox untuk bergerak (Ambarita et al., 2019).

\subsection{Flowchart Sistem Kerja}

Pada gambar 2 menjelaskan mengenai proses bekerjanya alat penala konstanta proporsional pada robot line follower berbasis website. Dimulai dari proses inisialisasi pada arduino uno dan wemos D1 mini sampai berubahnya nilai konstanta proporsional (Saleh \& Haryanti, 2017). 


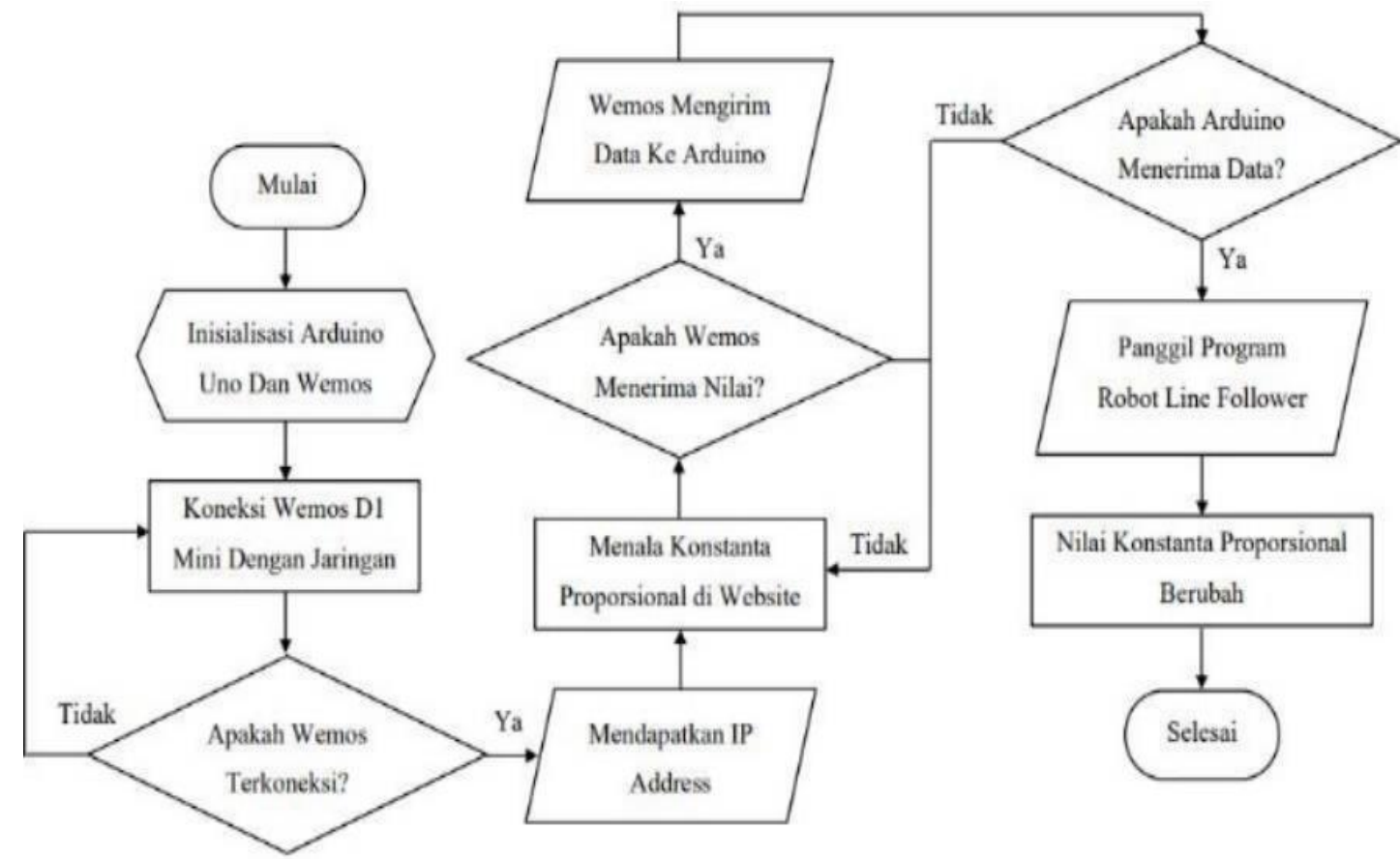

Sumber: Hasil Penelitian (2021)

Gambar 3. Diagram Metode Penelitian

Flowchart pada gambar 3 adalah proses bekerjanya alat penala konstanta proporsional pada robot line follower berbasis website. Dimulai dari proses inisialisasi pada arduino uno dan wemos D1 mini. Kemudian langkah selanjutnya adalah melakukan koneksi antara wemos D1 mini dengan jaringan untuk mendapatkan nilai IP address. IP address ini diperlukan untuk membuka halaman website penalaan konstanta proporsional. Setelah mendapatkan IP address, proses selanjutnya adalah menala nilai konstanta proporsional pada sebuah website yang ada pada IP tersebut. Penalaan nilai konstanta ini kemudian akan dikirimkan data nya melalui wemos D1 mini yang akan dilanjutkan pada arduino uno untuk dilakukan perubahan nilai konstanta proporsionalnya. Jika nilai penalaannya berhasil dikirimkan pada arduino uno, maka nilai konstanta proporsional berhasil dilakukan perubahan.

\section{Hasil dan Pembahasan}

Pengujian yang dilakukan pada alat penala kendali proporsional pada robot line follower berbasis website ini dilakukan tiga tahapan antara lain yaitu pengujian unit, pengujian integrasi dan pengujian sistem.

\subsection{Pengujian Unit}

\section{Pengujian pada Sensor TCRT5000}

Tabel 1 menjelaskan dari hasil pengujian pada sensor tcrt500 dimana untuk tegangan input pada sensor ini adalah 5 vdc baik dalam keadaan high maupun low. Sedangkan, tegangan output pada sensor ini bekerja diantara 3,2-4 vdc ketika dalam keadaan sensor high dan 3-4,2 vds ketika dalam keadaan sensor low. 
Tabel 1. Hasil Pengujian pada Sensor TCRT5000

\begin{tabular}{clccc}
\hline \multirow{2}{*}{ No Sensor } & \multirow{2}{*}{ Input $(\mathrm{Vdc})$} & \multicolumn{2}{c}{ Output (Vdc) } \\
\cline { 4 - 5 } & & 5 & High & Low \\
\hline 1 & Sensor Kanan 1 & 5 & 4,6 & 4,2 \\
\hline 2 & Sensor Kanan 2 & 5 & 4 & 4,1 \\
\hline 3 & Sensor Kanan 3 & 5 & 3,4 & 4,2 \\
\hline 4 & Sensor Kiri 1 & 5 & 3,2 & 3,2 \\
\hline 5 & Sensor Kiri 2 & 5 & 3,6 & 3,4 \\
\hline 6 & Sensor Kiri 3 & & &
\end{tabular}

Sumber: Hasil Penelitian (2021)

\section{Pengujian pada Gearbox dan Driver L298N}

Tabel 2 menjelaskan dari hasil pengujian pada gearbox dan driver motor L298n dimana untuk tegangan input dalam pengujian ini disemua kondisi baik kanan maju, kanan mundur, kiri maju, kiri mundur, maju maupun mundur yaitu bekerja pada tegangan 5-8 vdc, sedangkan untuk tegangan output pada semua kondisi bekerja pada tegangan 2,4-4,1 vdc.

Tabel 2. Hasil Pengujian pada Gearbox dan Driver L298N

\begin{tabular}{|c|c|c|c|}
\hline No & Kondisi & Input (Vdc) & Output (Vdc) \\
\hline 1 & Kanan Maju & $5-8$ & 3,7 \\
\hline 2 & Kanan Mundur & $5-8$ & 3,2 \\
\hline 3 & Kiri Maju & $5-8$ & 4 \\
\hline 4 & Kiri Mundur & $5-8$ & 4,1 \\
\hline 5 & Maju & $5-8$ & 2,4 \\
\hline 6 & Mundur & $5-8$ & 2,4 \\
\hline
\end{tabular}

Sumber: Hasil Penelitian (2021)

\section{Pengujian Pada Wemos D1 Mini}

Tabel 3 menjelaskan tentang tegangan input pada wemos d1 mini sebesar 3,3 vdc dan tegangan output pada wemos d1 mini sebesar 3 vdc pada pin D1.

Tabel 3. Hasil Pengujian pada Wemos D1 Mini

\begin{tabular}{ccc}
\hline No & Input (Vdc) & Output (Vdc) \\
\hline 1 & 3,3 & 3 (D1) \\
\hline Sumber: Hasil Penelitian (2021) &
\end{tabular}

\section{Pengujian pada Arduino IDE}

Berikut ini merupakan program pada arduino ide mengenai robot line follower yang telah diburning ke arduino uno.

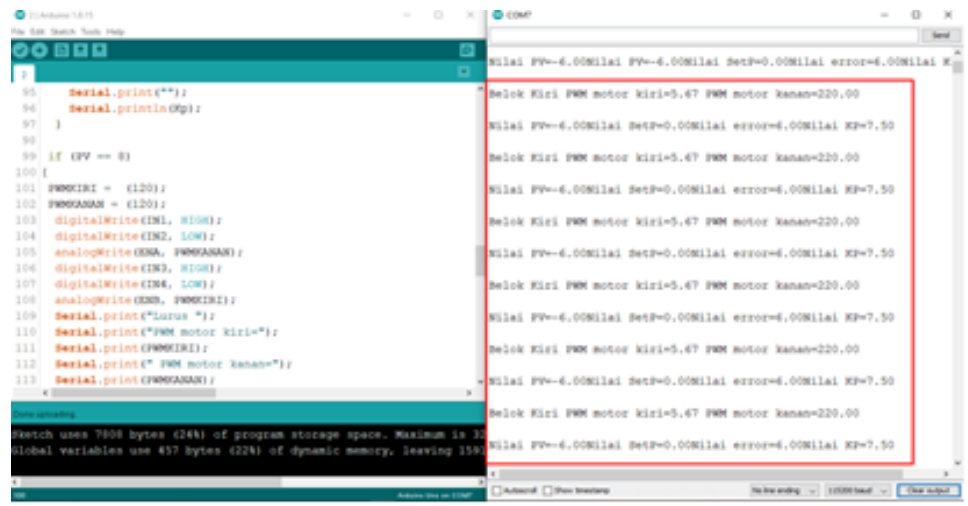

Sumber: Hasil Penelitian (2021)

Gambar 4. Hasil Burning Program Arduino IDE Robot Line follower 
Pada gambar 5 merupakan program pada arduino ide mengenai wemos D1 mini dan program untuk tampilan pada server website yang telah diburning ke wemos $\mathrm{d} 1 \mathrm{mini}$.

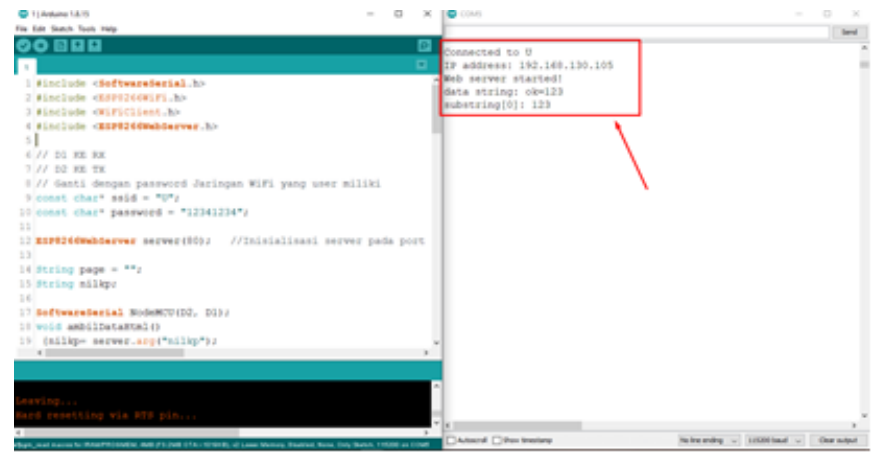

Sumber: Hasil Penelitian (2021)

Gambar 5. Hasil Burning Program Arduino IDE Wemos D1 Mini

\section{Pengujian pada Server Website}

Pada Gambar 6 merupakan tampilan server website setelah dilakukan proses penalaan nilai konstanta proporsional.

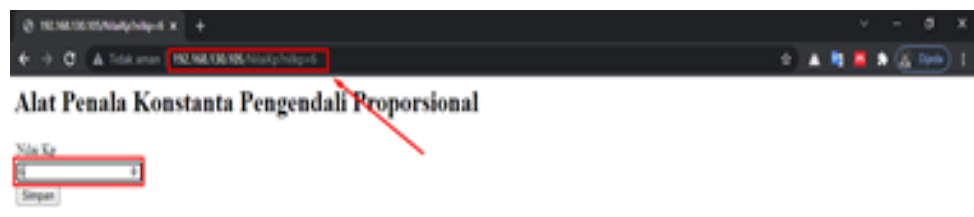

Sumber: Hasil Penelitian (2021)

Gambar 6. Hasil Tampilan Website Sesudah Penalaan

\subsection{Pengujian Integrasi}

\section{Pengujian Perangkat Keras Arduino uno Dengan Gearbox, Driver L298N, Dan Sensor TCRT5000}

Tabel 4 menjelaskan tentang hasil pengujian perangkat keras arduino uno dengan gearbox, driver 1298n dan sensor tcrt5000 telihat pada tabel 4 menerangkan bahwa setiap pembacaan sensor tcrt5000 akan terjadi perubahan kondisi gearbox dan driver I298n sehingga terjadilah pergerakan pada robot line follower baik itu belok kanan, belok kiri maju maupun stop.

Tabel 4. Hasil Pengujian Perangkat Keras Arduino uno Dengan Gearbox, Driver L298N, dan Sensor TCRT5000

\begin{tabular}{|c|c|c|c|c|c|c|c|c|}
\hline \multirow[t]{2}{*}{ No } & \multicolumn{3}{|c|}{$\begin{array}{c}\text { Sensor Kanan } \\
\text { Membaca Garis } \\
\text { Hitam }\end{array}$} & \multicolumn{3}{|c|}{$\begin{array}{c}\text { Sensor Kiri } \\
\text { Membaca Garis } \\
\text { Hitam }\end{array}$} & \multirow[t]{2}{*}{$\begin{array}{c}\text { Kondisi Gearbox \& } \\
\text { Driver L298N }\end{array}$} & \multirow[t]{2}{*}{ Kondisi Robot } \\
\hline & 1 & 2 & 3 & 1 & 2 & 3 & & \\
\hline 1 & $\sqrt{ }$ & - & - & - & - & - & Maju & Belok Kanan \\
\hline 2 & - & $\sqrt{ }$ & - & - & - & - & Maju & Belok Kanan \\
\hline 3 & - & - & $\sqrt{ }$ & - & - & - & Maju & Belok Kanan \\
\hline 4 & - & - & - & $\sqrt{ }$ & - & - & Maju & Belok Kiri \\
\hline 5 & - & - & - & - & $\sqrt{ }$ & - & Maju & Belok Kiri \\
\hline 6 & - & - & - & - & - & $\sqrt{ }$ & Maju & Belok Kiri \\
\hline 7 & $\sqrt{ }$ & $\sqrt{ }$ & - & - & - & - & Maju & Belok Kanan \\
\hline 8 & - & $\sqrt{ }$ & $\sqrt{ }$ & - & - & - & Maju & Balok Kanan \\
\hline 9 & - & - & - & $\sqrt{ }$ & $\sqrt{ }$ & - & Maju & Belok Kiri \\
\hline
\end{tabular}




\begin{tabular}{|c|c|c|c|c|c|c|c|c|}
\hline \multirow[t]{2}{*}{ No } & \multicolumn{3}{|c|}{$\begin{array}{c}\text { Sensor Kanan } \\
\text { Membaca Garis } \\
\text { Hitam }\end{array}$} & \multicolumn{3}{|c|}{$\begin{array}{c}\text { Sensor Kiri } \\
\text { Membaca Garis } \\
\text { Hitam } \\
\end{array}$} & \multirow[t]{2}{*}{$\begin{array}{c}\text { Kondisi Gearbox \& } \\
\text { Driver L298N }\end{array}$} & \multirow[t]{2}{*}{ Kondisi Robot } \\
\hline & 1 & 2 & 3 & 1 & 2 & 3 & & \\
\hline 1 & $\sqrt{ }$ & - & - & - & - & - & Maju & Belok Kanan \\
\hline 10 & - & - & - & - & $\sqrt{ }$ & $\sqrt{ }$ & Maju & Belok Kiri \\
\hline 11 & $\sqrt{ }$ & $\sqrt{ }$ & $\sqrt{ }$ & - & - & - & Maju & Belok Kanan \\
\hline 12 & - & - & - & $\sqrt{ }$ & $\sqrt{ }$ & $\sqrt{ }$ & Maju & Belok Kiri \\
\hline 13 & $\sqrt{ }$ & $\sqrt{ }$ & $\sqrt{ }$ & $\sqrt{ }$ & $\sqrt{ }$ & $\sqrt{ }$ & Maju & Maju \\
\hline 14 & - & - & - & - & - & - & Stop & Stop \\
\hline
\end{tabular}

Sumber: Hasil Penelitian (2021)

\subsection{Pengujian Sistem}

\section{Pengambilan Data yang Dikirim dan Diterima}

Tabel 5 menjelaskan bahwa pada pengujian data yang dikirirm dan diterima ini dari 15 kali percobaan pengujian data dapat dikirim 15 kali dan diterima hanya 13 kali data. Maka dari itu dari pengujian ini terjadi 2 data yang tidak dapat diterima.

Tabel 5. Hasil Pengujian Pengambilan Data yang Dikirim dan Diterima

\begin{tabular}{cccccc}
\hline No & Percobaan & $\begin{array}{c}\text { Data Yang Dikirim (Tampilan Pada } \\
\text { Serial Monitor Wemos D1 Mini) }\end{array}$ & $\begin{array}{c}\text { Data Yang Diterima (Tampilan } \\
\text { Pada Serial Monitor Robot Line } \\
\text { follower) }\end{array}$ \\
\cline { 3 - 6 } & & $\begin{array}{c}\text { Nilai KP Yang } \\
\text { Dikirimkan }\end{array}$ & Status & $\begin{array}{c}\text { Nilai KP Yang } \\
\text { Diterima }\end{array}$ & Status \\
\hline 1 & Percobaan 1 & 1 & OK & 1 & OK \\
\hline 2 & Percobaan 2 & 2 & OK & 2 & OK \\
\hline 3 & Percobaan 3 & 3 & OK & - & OK \\
\hline 4 & Percobaan 4 & 4 & OK & 4 & OK \\
\hline 5 & Percobaan 5 & 5 & OK & 5 & OK \\
\hline 6 & Percobaan 6 & 6 & OK & 6 & OK \\
\hline 7 & Percobaan 7 & 7 & OK & 7 & - \\
\hline 8 & Percobaan 8 & 8 & OK & - & OK \\
\hline 9 & Percobaan 9 & 9 & OK & 10 & OK \\
\hline 10 & Percobaan 10 & 10 & OK & 11 & OK \\
\hline 11 & Percobaan 11 & 11 & OK & 12 & OK \\
\hline 12 & Percobaan 12 & 12 & OK & 13 & OK \\
\hline 13 & Percobaan 13 & 13 & OK & 14 & OK \\
\hline 14 & Percobaan 14 & 14 & OK & 15 & OK \\
\hline 15 & Percobaan 15 & 15 & & &
\end{tabular}

Sumber: Hasil Penelitian (2021)

\section{Pengambilan Data Waktu Tunda dan Terima}

a. Pengujian Pengambilan Data Pertama Waktu Kirim dan Terima Menggunakan Jaringan Seluler Handphone.

Tabel 6 menjelaskan tentang pengujian pengambilan data pertama waktu kirim dan teima menggunakan jaringan seluler handphone. Pada pengujian ini waktu yang dibutuhkan paling lama yaitu 09.50,0 pada percobaan 1 sedangkan waktu yang dibutuhkan paling cepat yaitu 00.05,2 pada percobaan 11. 
Tabel 6 Hasil Pengujian Pengambilan Data Pertama Waktu Kirim dan Terima Menggunakan Jaringan Seluler Handphone

\begin{tabular}{cccccc}
\hline No & Percobaan & \multicolumn{2}{c}{$\begin{array}{c}\text { Data Yang Dikirim (Tampilan Pada } \\
\text { Serial Monitor Wemos D1 Mini) }\end{array}$} & \multicolumn{2}{c}{$\begin{array}{c}\text { Data Yang Diterima (Tampilan Pada } \\
\text { Serial Monitor Robot Line follower) }\end{array}$} \\
\cline { 3 - 6 } & $\begin{array}{c}\text { Nilai KP Yang } \\
\text { Dikirimkan }\end{array}$ & $\begin{array}{c}\text { Data Diterima } \\
\text { Wemos }\end{array}$ & $\begin{array}{c}\text { Nilai KP Yang } \\
\text { Diterima }\end{array}$ & Waktu Tunda \\
\hline 1 & Percobaan 1 & 1 & OK & 1 & $09.50,0$ \\
\hline 2 & Percobaan 2 & 2 & OK & 2 & $02.45,0$ \\
\hline 3 & Percobaan 3 & 3 & OK & - & - \\
\hline 4 & Percobaan 4 & 4 & OK & 4 & $00.45,3$ \\
\hline 5 & Percobaan 5 & 5 & OK & 5 & $04.02,0$ \\
\hline 6 & Percobaan 6 & 6 & OK & 6 & $04.10,0$ \\
\hline 7 & Percobaan 7 & 7 & OK & 7 & $02.02,0$ \\
\hline 8 & Percobaan 8 & 8 & OK & 8 & $01.01,0$ \\
\hline 9 & Percobaan 9 & 9 & OK & - & - \\
\hline 10 & Percobaan 10 & 10 & OK & 10 & $00.21,9$ \\
\hline 11 & Percobaan 11 & 11 & OK & 11 & $00.05,2$ \\
\hline 12 & Percobaan 12 & 12 & OK & 12 & $00.07,0$ \\
\hline 13 & Percobaan 13 & 13 & OK & 13 & $00.08,4$ \\
\hline 14 & Percobaan 14 & 14 & OK & 14 & $00.27,0$ \\
\hline 15 & Percobaan 15 & 15 & OK & 15 & $00.53,0$ \\
\hline
\end{tabular}

Sumber: Hasil Penelitian (2021)

b. Pengujian Pengambilan Data Pertama Waktu Kirim dan Terima Menggunakan Jaringan WiFi.

Tabel 7 menjelaskan pengujian pengambilan data pertama waktu kirim dan teima menggunakan jaringan Wi-Fi. Waktu yang dibutuhkan paling lama yaitu 00.01,5 pada percobaan 2 sedangkan waktu dibutuhkan paling cepat yaitu 00.00,8 pada percobaan 11 .

Tabel 7. Hasil Pengujian Pengambilan Data Pertama Waktu Kirim dan Terima Menggunakan Jaringan Wi-Fi

\begin{tabular}{cccccc}
\hline No & Percobaan & $\begin{array}{c}\text { Data Yang Dikirim (Tampilan Pada } \\
\text { Serial Monitor Wemos D1 Mini) }\end{array}$ & \multicolumn{2}{c}{$\begin{array}{c}\text { Data Yang Diterima (Tampilan } \\
\text { Pada Serial Monitor Robot Line } \\
\text { follower) }\end{array}$} \\
\cline { 3 - 7 } & $\begin{array}{c}\text { Nilai KP Yang } \\
\text { Dikirimkan }\end{array}$ & $\begin{array}{c}\text { Data Diterima } \\
\text { Wemos }\end{array}$ & $\begin{array}{c}\text { Nilai KP Yang } \\
\text { Diterima }\end{array}$ & Waktu Tunda \\
\hline 1 & Percobaan 1 & 1 & OK & 1 & $00.01,4$ \\
\hline 2 & Percobaan 2 & 2 & OK & 2 & $00.01,5$ \\
\hline 3 & Percobaan 3 & 3 & OK & 3 & $00.01,3$ \\
\hline 4 & Percobaan 4 & 4 & OK & 4 & $00.01,2$ \\
\hline 5 & Percobaan 5 & 5 & OK & 5 & $00.01,2$ \\
\hline 6 & Percobaan 6 & 6 & OK & 6 & $00.01,0$ \\
\hline 7 & Percobaan 7 & 7 & OK & 7 & $00.01,1$ \\
\hline 8 & Percobaan 8 & 8 & OK & 8 & $00.01,1$ \\
\hline 9 & Percobaan 9 & 9 & OK & 9 & $00.01,0$ \\
\hline 10 & Percobaan 10 & 10 & OK & 10 & $00.00,9$ \\
\hline 11 & Percobaan 11 & 11 & OK & 11 & $00.00,9$ \\
\hline 12 & Percobaan 12 & 12 & OK & 12 & $00.00,9$ \\
\hline 13 & Percobaan 13 & 13 & OK & 13 & $00.00,8$ \\
\hline 14 & Percobaan 14 & 14 & OK & 14 & $00.00,8$ \\
\hline 15 & Percobaan 15 & 15 & OK & 15 & $00.00,9$ \\
\hline Sumber: Hasil Penelitian (2021) & & & & \\
\hline
\end{tabular}


c. Pengujian Perbedaan Waktu Tunda Setiap 5 Kali Data yang Diterima Menggunakan Jaringan Seluler Handphone.

Tabel 8 menjelaskan tentang pengujian perbedaan waktu tunda setiap 5 kali data diterima menggunakan jaringan seluler handphone. Pada pengujian ini waktu yang dibutuhkan paling lama untuk 5 kali data diterima yaitu 11.39,2 pada percobaan 1 sedangkan waktu yang dibutuhkan paling cepat untuk 5 kali data diterima yaitu 00.19,1 pada percobaan 10.

Tabel 8. Hasil Pengujian Perbedaan Waktu Tunda Setiap 5 Kali Data yang Diterima

Menggunakan Jaringan Seluler Handphone

\begin{tabular}{ccccccc}
\hline \multirow{2}{*}{ No } & $\begin{array}{c}\text { Nilai KP } \\
\text { Yang }\end{array}$ & \multicolumn{5}{c}{ Perbedaan Waktu Tunda Dari Mulai Data Dikirimkan Sampai Data Diterima } \\
\cline { 3 - 7 } & Dikirim & 1 & 2 & 3 & 4 & 5 \\
\hline 1 & 1 & $00.05,1$ & $00.39,6$ & $09.53,9$ & $10.03,2$ & $11.39,2$ \\
\hline 2 & 2 & $01.48,3$ & $02.26,5$ & $06.40,2$ & $06.55,0$ & $09.11,4$ \\
\hline 3 & 3 & $01.25,5$ & $02.25,4$ & $03.08,1$ & $07.02,8$ & $08.57,5$ \\
\hline 4 & 4 & $01.09,7$ & $01.17,4$ & $02.56,5$ & $03.25,4$ & $10.14,2$ \\
\hline 5 & 5 & $00.06,7$ & $03.39,9$ & $06.51,4$ & $09.43,4$ & $09.44,0$ \\
\hline 6 & 6 & $00.02,1$ & $02.18,2$ & $02.24,6$ & $04.04,9$ & $05.06,5$ \\
\hline 7 & 7 & $01.06,8$ & $01.22,5$ & $06.56,5$ & $08.30,9$ & $08.35,9$ \\
\hline 8 & 8 & $00.47,9$ & $00.49,6$ & $01.57,7$ & $06.06,9$ & $07.22,0$ \\
\hline 9 & 9 & $02.49,3$ & $02.51,5$ & $03.17,2$ & $03.58,8$ & $06.33,1$ \\
\hline 10 & 10 & $00.04,1$ & $00.09,6$ & $00.11,5$ & $00.15,2$ & $00.19,1$ \\
\hline 11 & 11 & $00.04,1$ & $00.37,7$ & $00.50,9$ & $00.53,0$ & $00.58,1$ \\
\hline 12 & 12 & $00.06,5$ & $00.07,7$ & $00.30,1$ & $00.40,1$ & $00.44,1$ \\
\hline 13 & 13 & $00.08,2$ & $00.14,0$ & $00.16,7$ & $00.20,0$ & $00.21,3$ \\
\hline 14 & 14 & $00.29,0$ & $00.30,1$ & $00.32,7$ & $00.39,0$ & $01.10,0$ \\
\hline 15 & 15 & $00.05,6$ & $00.08,4$ & $00.26,0$ & $00.36,4$ & $00.42,2$ \\
\hline
\end{tabular}

Gambar 7 merupakan grafik dari perbedaan waktu tunda setiap 5 kali data yang diterima menggunakan jaringan Seluler Handphone.

\section{Grafik Perbedaan Waktu Setiap 5 Kali Data}

\section{Diterima}
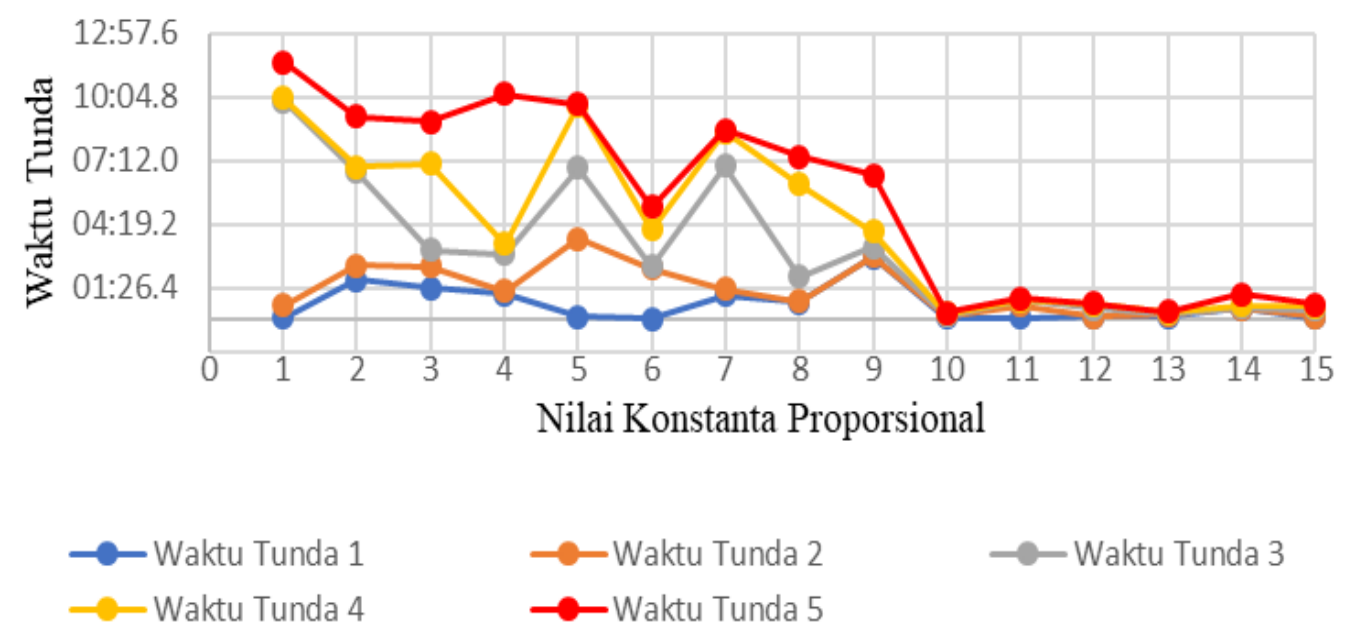

- Waktu Tunda 3

Sumber: Hasil Penelitian (2021)

Gambar 7. Grafik Perbedaan Waktu Setiap 5 Kali Data Diterima Menggunakan Jaringan Seluler Handphone 
d. Pengujian Perbedaan Waktu Tunda Setiap 5 Kali Data yang Diterima Menggunakan Jaringan Wi-Fi.

Tabel 9 menjelaskan tentang pengujian perbedaan waktu tunda setiap 5 kali data diterima menggunakan jaringan Wi-Fi. Pada pengujian ini waktu yang dibutuhkan paling lama untuk 5 kali data diterima yaitu $00.10,5$ pada percobaan 1 sedangkan waktu yang dibutuhkan paling cepat untuk 5 kali data diterima yaitu 00.04,2 pada percobaan 14.

Tabel 9. Hasil Pengujian Perbedaan Waktu Tunda Setiap 5 Kali Data yang Diterima

Menggunakan Jaringan $\mathrm{Wi}-\mathrm{Fi}$

\begin{tabular}{ccccccc}
\hline \multirow{2}{*}{ No } & $\begin{array}{c}\text { Nilai KP } \\
\text { Yang } \\
\text { Dikirim }\end{array}$ & \multicolumn{5}{c}{ Perbedaan Waktu Tunda Dari Mulai Data Dikirimkan Sampai Data Diterima } \\
\cline { 3 - 7 } & 1 & $00.05,1$ & $00.06,3$ & $00.07,6$ & $00.08,7$ & 5 \\
\hline 1 & 2 & $00.02,4$ & $00.04,2$ & $00.05,4$ & $00.06,4$ & $00.10,5$ \\
\hline 2 & 3 & $00.01,2$ & $00.02,2$ & $00.03,5$ & $00.04,3$ & $00.05,9$ \\
\hline 3 & 4 & $00.03,9$ & $00.04,8$ & $00.05,5$ & $00.07,2$ & $00.08,5$ \\
\hline 4 & 5 & $00.01,2$ & $00.02,6$ & $00.03,2$ & $00.03,5$ & $00.04,7$ \\
\hline 5 & 6 & $00.01,3$ & $00.02,4$ & $00.02,9$ & $00.03,7$ & $00.05,0$ \\
\hline 6 & 7 & $00.01,0$ & $00.02,2$ & $00.02,9$ & $00.04,1$ & $00.04,9$ \\
\hline 7 & 8 & $00.01,6$ & $00.05,3$ & $00.05,9$ & $00.08,7$ & $00.09,8$ \\
\hline 8 & 9 & $00.01,4$ & $00.02,3$ & $00.03,1$ & $00.04,3$ & $00.05,7$ \\
\hline 9 & 10 & $00.01,1$ & $00.02,3$ & $00.03,2$ & $00.04,2$ & $00.05,2$ \\
\hline 10 & 11 & $00.01,4$ & $00.02,0$ & $00.02,6$ & $00.03,9$ & $00.05,6$ \\
\hline 11 & 12 & $00.01,1$ & $00: 02,0$ & $00.03,0$ & $00.03,7$ & $00.04,8$ \\
\hline 12 & 13 & $00.02,3$ & $00.02,5$ & $00.04,7$ & $00.06,5$ & $00.07,2$ \\
\hline 13 & 14 & $00.00,9$ & $00.01,4$ & $00.02,0$ & $00.03,2$ & $00.04,2$ \\
\hline 14 & 14 & $00.01,0$ & $00.02,2$ & $00.02,9$ & $00.04,0$ & $00.05,1$ \\
\hline 15 & 15 & & & &
\end{tabular}

Gambar 8 merupakan grafik dari perbedaan waktu tunda setiap 5 kali data yang diterima menggunakan jaringan Wi-Fi.

\section{Grafik Perbedaan Waktu Setiap 5 Kali Data Diterima}
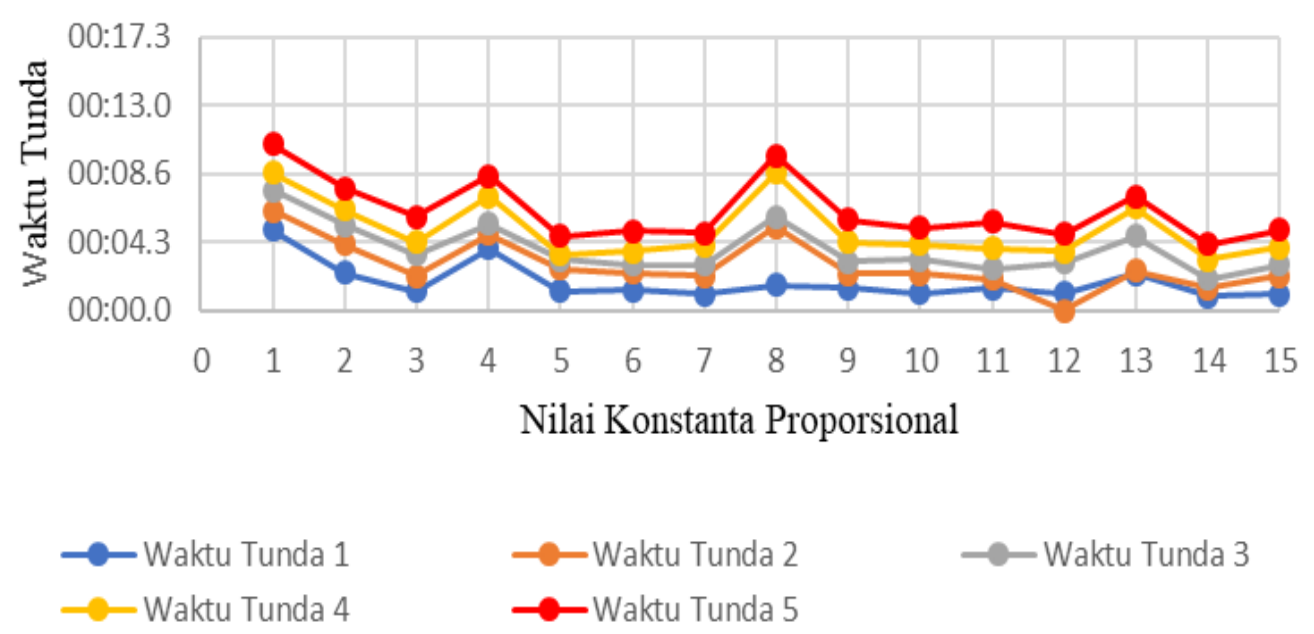

- Waktu Tunda 3

Sumber: Hasil Penelitian (2021)

Gambar 8. Grafik Perbedaan Waktu Setiap 5 Kali Data Diterima Menggunakan Jaringan Wi-Fi 


\section{Kondisi Pada Server Website}

Tabel 10 menjelaskan bahwa pada pengujian kondisi pada server website dari 15 kali percobaan pengujian kondisi server website dapat bekerja dengan baik.

Tabel 10. Hasil Pengujian Kondisi Pada Server Website

\begin{tabular}{clcc}
\hline No & \multicolumn{1}{c}{ Percobaan } & $I P$ & Kondisi Server Website \\
\hline 1 & Percobaan 1 & 192.168 .218 .105 & OK \\
\hline 2 & Percobaan 2 & 192.168 .218 .105 & OK \\
\hline 3 & Percobaan 3 & 192.168 .218 .105 & OK \\
\hline 4 & Percobaan 4 & 192.168 .218 .105 & OK \\
\hline 5 & Percobaan 5 & 192.168 .218 .105 & OK \\
\hline 6 & Percobaan 6 & 192.168 .218 .105 & OK \\
\hline 7 & Percobaan 7 & 192.168 .218 .105 & OK \\
\hline 8 & Percobaan 8 & 192.168 .218 .105 & OK \\
\hline 9 & Percobaan 9 & 192.168 .218 .105 & OK \\
\hline 0 & Percobaan 10 & 192.168 .218 .105 & OK \\
\hline 11 & Percobaan 11 & 192.168 .218 .105 & OK \\
\hline 12 & Percobaan 12 & OK \\
\hline 13 & Percobaan 13 & 192.168 .218 .105 & OK \\
\hline 14 & Percobaan 14 & 192.168 .218 .105 & OK \\
\hline 15 & Percobaan 15 & 192.168 .218 .105 & OK \\
\hline
\end{tabular}

Sumber: Hasil Penelitian (2021)

\section{Kesimpulan}

Berdasarkan pembahasan dan pengujian pada alat ini dapat disimpulkan bahwa data atau nilai konstanta proporsional yang di input dari website dapat dikirimkan pada robot line follower secara jarak, realtime tanpa burning ulang program dengan memaanfaatkan transmisi data serial antara wemos dan arduino yang sumber data berasal dari sebuah situs yang di pasang pada wemos. Kemudian wemos berhasil bekerja sebagai penyedia layanan website untuk menampung dan mentransmisikan nilai kendali proporsional, wemos membutuhkan waktu tunda paling lama adalah 09.50,0 dan paling cepat adalah 00.00,8.

\section{Daftar Pustaka}

Abidin, L. (n.d.). Materi VIII Pengendali Proporsional Integral Derivatif (PID). Teknik Elektro Universitas Widyagama Malang. https://www.academia.edu/8817330/MATERI_8_Pengendali_Proporsional_Integral_Deriv atif

Ambarita, J., P, R. A., \& Wibowo, A. S. (2019). Rancang Bangun Prototipe Smarthome Berbasis Internet of Things (IoT) Menggunakan APlikasi BLYNK dengan Modul ESP 8266. EProceeding of Engi, 6(2), 3006-3013.

Diyati, F. (2016). Rancang Bangun Robot Line follower Berbasis Cahaya Tampak [Universitas Aairlangga]. https://repository.unair.ac.id/54817/13/FV.OSI.39-16 Diy r-min.pdf

Ferdiansyah, F. (n.d.). Teori Kontrol PID (Proportional-Integral-Derivative). https://www.academia.edu/9928544/Teori_Kontrol_PID_Proportional_Integral_Derivative Khalif, M. I., Syauqi, D., \& Maulana, R. (2018). Pengembangan Sistem Penghitung Langkah 
Kaki Hemat Daya Berbasis Wemos D1 Mini. Jurnal Pengembangan Teknologi Informasi Dan IImu Komputer, 2(6), 2548-2964. http://j-ptiik.ub.ac.id/index.php/jptiik/article/view/1567

Limantara, A. D., Candra, A. I., \& Mudjanarko, S. W. (2017). Manajemen Data Lalu Lintas Kendaraan Berbasis Sistem Internet Cerdas Ujicoba Implementasi di Laboratorium Universitas Kadiri. Seminar Nasional Sains Dan Teknologi 2017, 4(November), 1-11. https://jurnal.umj.ac.id/index.php/semnastek/article/view/1808/1486

Miftahul, H., Firdaus, \& Derisma. (2016). Pengontrolan Kecepatan Mobile Robot Line follower Dengan Sistem Kendali PID. Jurnal TELKA - Telekomunikasi, Elektronika, Komputasi Dan Kontrol, 2(2), 150-159. https://doi.org/10.15575/telka.v2n2.150-159

Saleh, M., \& Haryanti, M. (2017). Rancang Bangun Sistem Keamanan Rumah Menggunakan Relay. Jurnal Teknologi Elektro, UniversitasMercu Buana, 8(2), 87-94. https://media.neliti.com/media/publications/141935-ID-perancangan-simulasi-sistempemantauan-p.pdf 